Olena Grishnova, Doctor of Economics, Professor, Taras Shevchenko National University of Kyiv, 90 A, Vul. Vasylkivska str., Kyiv, 03022, Ukraine,

ORCID: 0000-0002-4178-1662

ResearcherID: G-1740-2017

Kateryna Bereziuk, $\mathrm{PhD}$ Student, Institute of Industrial Economics, National Academy of Sciences of Ukraine 2 Zhelyabova Street, Kyiv, 03057, Ukraine ORCID: 0000-0001-6648-8596

\title{
ACTIVATION OF NUCLEAR TOURISM AS A FACTOR OF ENTERPRISE SOCIAL RESPONSIBILITY
}

This article explores the main trends in the development of industrial tourism around the world focusing on nuclear tourism. The dynamics of tourist flows into the Chornobyl zone and Ukrainian operating NPPs during 2015-2019 areanalyzed. The paper discusses the different aspects of nuclear tourism and presents it as a new component of social responsibility. The benefits and impacts of activization of nuclear tourism for communities and the enterprises are highlighted.

Keywords: nuclear energy tourism, social responsibility, industrial tourism, dark tourism, Chernobyl zone.

Relevance of research topic. Industrial tourism is not a new phenomenon: factory visits are possible since decades, but their growing popularity and spreading was not experienced before. Today, industrial tourism is becoming increasingly popular. It focuses on the unconventional beauty of steel manufacturing plants, quarries and mines. Old factories, breweries and mines are becoming popular tourist attractions.

Formulation of the problem. Industrial tourism has become increasingly popular in recent years. The world has accumulated considerable experience in the development of nuclear tourism, which Ukraine successfully adopts, but in our country preferences for the development of industrial tourism as a component of social responsibilities are not yet fully understood.Therefore the purpose of the article is to analyze the dynamics of nuclear tourism development in Ukraine and in the world in the context of social responsibility. 
Analysis of recent researches and publications. The concept of «industrial tourism» was given attention as foreign publicists, as well as Ukrainian scientists. The issures of «industrial and nuclear tourism are widely discussed in the papers by A. Otgaar, N. Mazeikiene, E. Gerulaitienè, Dr.S.Jansirani, Mrs.Mangai.R. Stone, R. Hartmann, T. Seaton, R. Sharpley, L. White describe Hiroshima and Chernobyl as educational and emotional example of «dark tourism,» «grief tourism» or «battlefield tourism».

Despite numerous scientific researches, industrial tourism was analyzed as a part of economy, related to services industry. However, we propose to consider industrial tourism and specially nuclear turism as a part of enterprises social responsibility.

Presenting main material. The idea of visiting active and non-active firm emerged already in 17th century when the British nobility started to travel to the European mainland. In the 19th and 20th century increasing prosperity resulted in the development of industrial mass tourism [8].

Industrial tourism means that objects which were created not for being attractions (and in some cases it is not their primary function in the present) became tourist destinations. It means that sometimes the production itself can be a part of the attraction [3]. However, the term, «industrial tourism» is a bit misleading because not only industrial activities and facilities can become attractions in this type of tourism, but all kinds of economic activities and buildings.

According to thedifferent surveys, most important reasons for enterprises to offer tours are to:

$>$ Improve their image, especially for industries trying to counter negative publicity.

$>$ Improve the working morale of employees and attract new employees

$>$ Understand better what customer want

$>$ Create an economic benefit for organizations and the local community

Each country has its own unique industrial tourism destinations. For United States truly unique experience can be found in Detroit. It is the centre of the United States' automotive industry and an economic powerhouse. Detroit is a must-visit city for industrial tourism. Travellers can explore the history of Ford Motor Company at the Piquette Avenue Plant, where the Model T - the first affordable car for everyday Americans - was born. A few minutes away from Piquette Avenue, visitors can see manufacturing in action at the Ford Rouge Factory, the only Detroit automotive plant tour available to the public. The Rouge offers tours of its assembly plant, observation deck and legacy gallery - which houses five historic Ford cars. In Kawasaki, Japan, tourists are flocking to a new kind of attraction: a power plant. A truly unique experience can be found at the BMW Plant in Munich [1].

After the opening of the nuclear age the interest in everything atomic has increased upon. Today nuclear tourism becomes a new niche of industrial tourism. 
Nuclear tourism can be considered as a specific form of energy tourism. This specific area of tourism is characterized by the tourism attractiveness of industrial sites in the country, new technologies or power plants [9].

Nowadaysnuclear tourism became a new component of social responsibility. Nuclear tourism helps to to learn more about industry, environmental impact, operational risks.

One of the nuclear energy problems is the mistrust population to nuclear NPPs. In 2011, Ipsos conducted survey about attitudes of the population of different countries regarding nuclear energy. An international sample is that 18,787 adults in age 18-64 in the US and Canada, and age 16-64 in all other countries, were interviewed. Majorities in Germany, Italy, and Spain oppose nuclear energy (figure 1.1).

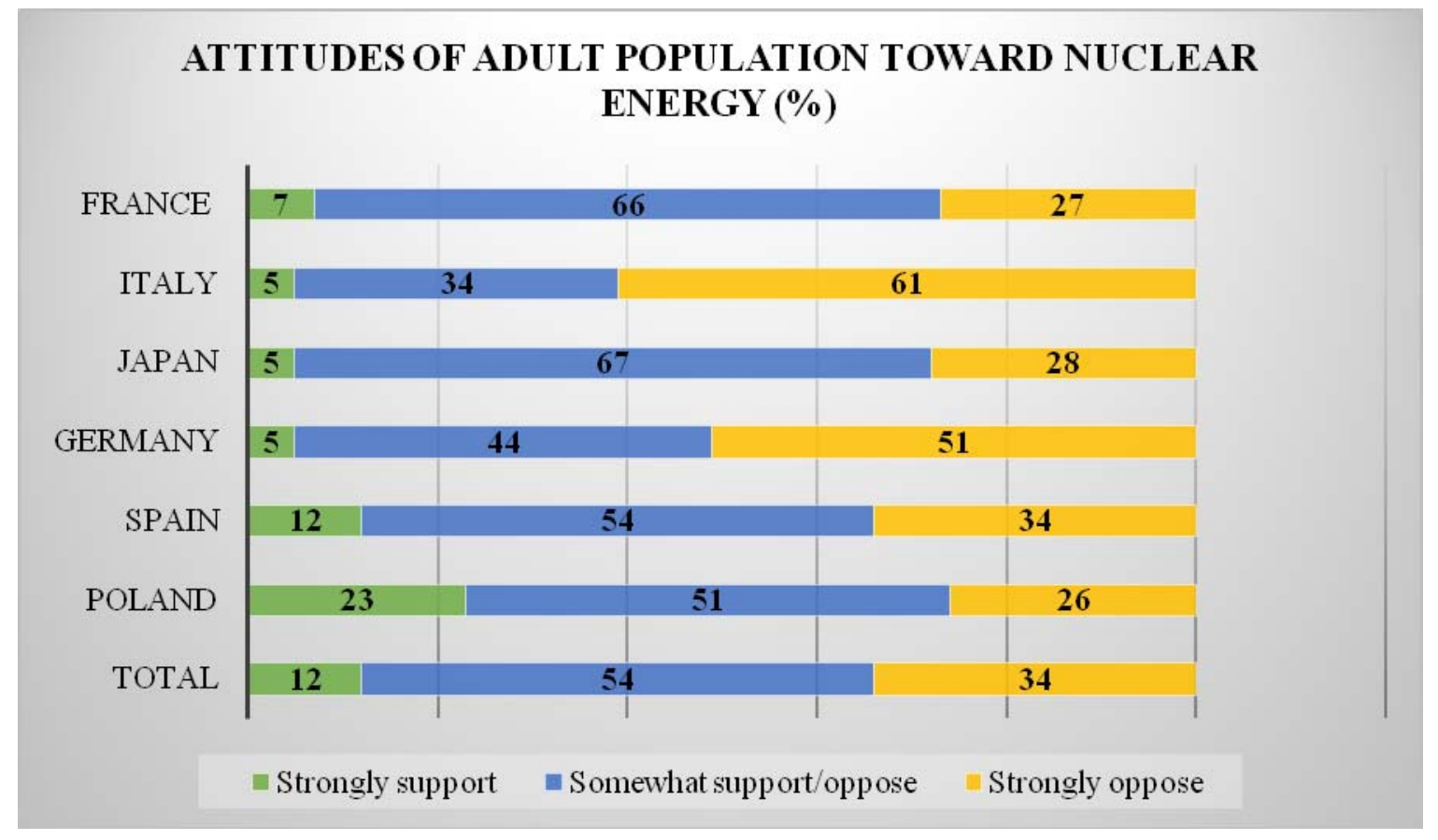

Fig. 1.1. Attitudes of adult population toward nuclear energy (\%)

Source: Ipsos survey: Global Citizen Reaction to the Fukushima Nuclear Plant Disaster [2]

In June-August of 2015 was held an all-Ukrainian survey on opinions and attitudes of the population of Ukraine regarding nuclear energy. According to this survey, 54\% Ukrainians hold on opinion that receiving cheap electricity from NPPs. They do not justify the risks that stand behind the nuclear energy sector [6].

Nuclear tourism facilitates communication with communities and refute myths about air pollution.

Many countries have their own nuclear power stations that attract tourists.

In 1985, the Philippines completed construction on a nuclear power plant that cost 88 billion Philippine pesos, but the Bataan plant was never used. In 2011, it finally opened - as a tourist attraction. The plant is offering tours in hopes of increasing support for nuclear power [1]. 
The public now has a way to embrace the history of the atomic age - through nuclear tourism. In the scientific literature there are several types of nuclear tourism [4]:

$>$ Energy tourism at the Information (visitors Centers of nuclear power plants;

Dark tourism in the places of nuclear disasters;

Military nuclear tourism

STEM education in nuclear tourism museums and NPP information centers.

Example of energy tourism at the information is Dukovany and Temelin Nuclear Power Plants (NPP). Information centers present an attractive journey to electricity from the atomic core in the midst of historic interiors and are providing variety of educational activities: visitors can learn about the exhibited models of the reactor and the reactor unit, deposition of spent nuclear fuel and get other technical information [4].

Another example of energy tourism is excursions and educational activities at 4 operating Ukrainian nuclear power plants. According to the «NNEG «Energoatom» information, the number of tourists in 2015-2019 was increased in 3 times (figure 1.2).

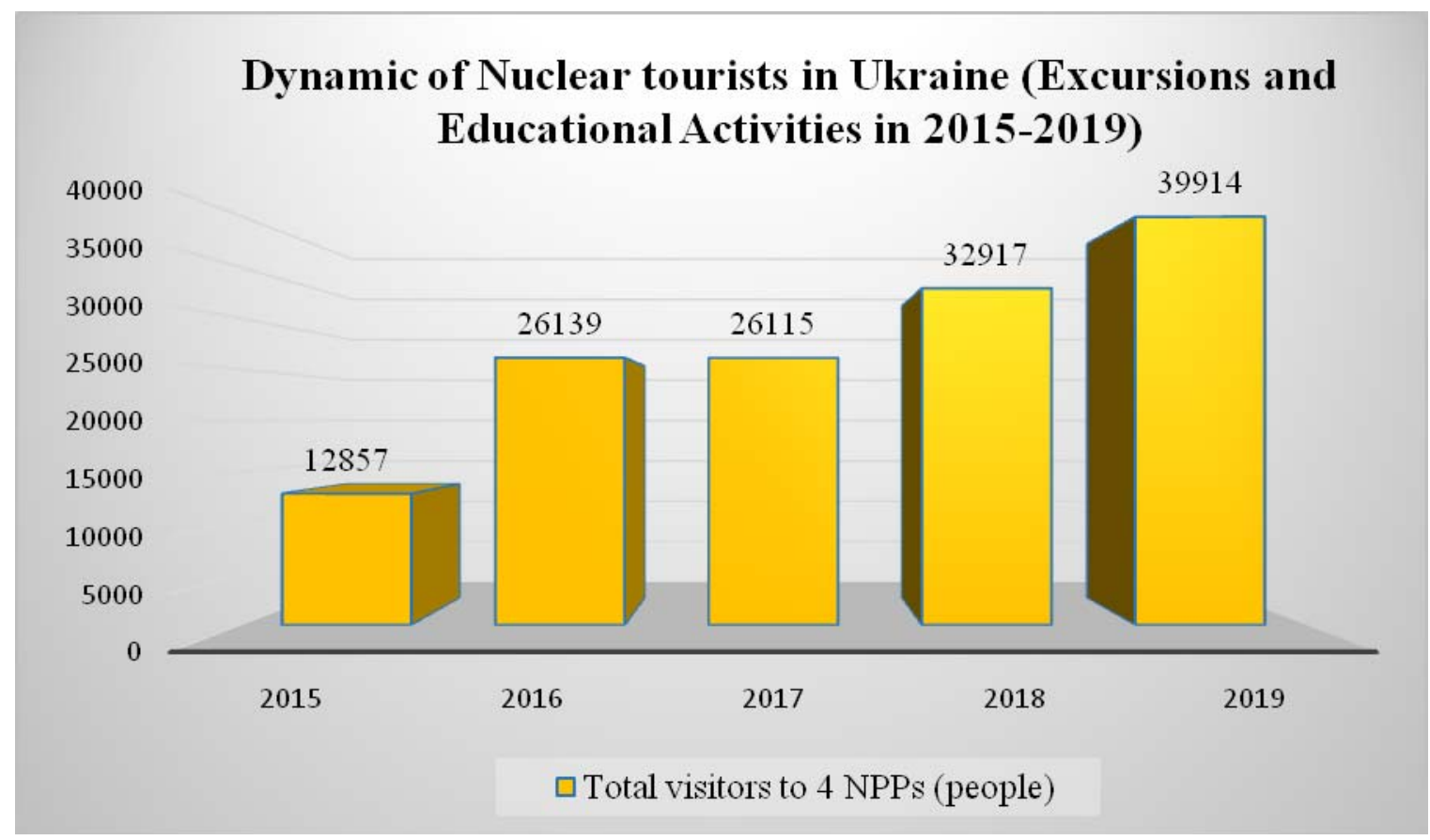

Fig. 1.2. Dynamic of Nuclear tourists in Ukraine (Excursions and Educational Activities in 2015-2019)

Source: «NNEG Company «Energoatom» [7]

In addition to excursions to the NPPs, virtual 3D tours and Information Centers were developed. For example, on Khmelnytskyi NPP employees inform the population about the activities NPP and prospects for its development.Anyone can visit Khmelnitsky Nuclear Power Plant. The staff of the information center organizes daily excursion tours for residents of the region, students and foreign delegations [10]. 
One of the emerging 'dark tourism' destinations is the Chernobyl power plant site and its surroundings. In recent years, the 'Chernobyl Exclusion Zone' (the area around the exploded Chernobyl reactor) has become quite popular among tourists.

A visit to the Chernobyl Exclusion Zone might appeal to visitors for various reasons. The area is like a Soviet time capsule having been left largely untouched for 30 years, which is very unique for those interested in modern history. The abandoned town of Pripyat appears particularly haunting. There are relatively few locations that have seen this level of desertion, so for those looking for unusual travel experiences, it's an interesting case. For those with an interest in finding out what happened via first-hand experiences rather than learning from a TV show or online article, it can be an educational travel experience.

The number of visitors is growing every year. According to the official information, the number of tourists for the last 5 years increased more than 7 times (16,3 thousands in 2015 and more than 120 thousands in 2019) [12].

Last year president of Ukraine Volodymyr Zelenskyy signed a Decree «On certain issues of the development of territories affected by radioactive contamination as a result of the Chernobyl disaster». The document envisages, in particular, the development and adoption of the Chernobyl Development Strategy as a tourist attraction [13].

Fukushima has become another popular example of the phenomenon known as dark tourism - a term for visiting sites associated with death and suffering. The Fukushima-1 disaster is called the worst tragedy after the Chernobyl accident.The Fukushima brand may forever be associated with nuclear catastrophe, but some residents, angered by persistent rumours about the dangers of even making brief visits to the area, are turning to tourism to show the world that, for some, life in Fukushima goes on. Previously, only experts, politicians, government officials and members of the press were allowed to be at the Nuclear power plant (NPP). The number of tourists for the last year was more than 10 thousand, to Tokyo 2020 this figure is planned to double [5].

Conclusion. Based on international experiences, nuclear tourism is a good example of unusual attractions and proves that not only nice and aesthetic objects can become destinations.

For many countries nuclear tourism is a field of the social responsibility. Such kind of tourismcontribute to enhancing scientific literacy on environmental issues, technical and engineering skills, develop responsible citizenship, knowledge on heritage and history, increase community confidence in nuclear energy.

The analysis of nuclear tourism in Ukraine showed that not only Chernobyl Exclusion Zonehas become quite popular among tourists. Also operating Ukrainian nuclear power plants have potential. In addition to excursions to the NPPs, virtual 3D tours and Information Centers were developed. It is a part of «NNEG Company «Energoatom» social responsibility. 


\section{REFERENCES}

1. BBC: The complicated allure of industrial tourism - 2011. All rights reserved. Retrieved from http://www.bbc.com/travel/story/20111007-the-complicatedallure-of-industrial-tourism

2. Ipsos survey (2011), «Global Citizen Reaction to the Fukushima Nuclear Plant Disaster»All rights reserved. Retrieved from https://web.archive.org/web/ 20141224033030/https://www.ipsos-mori.com/Assets/Docs/Polls/ipsos-globaladvisor-nuclear-power-june-2011.pdf

3. Jansirani, S. and Mangai, O. (2013),»Industrial Tourism: An Introduction», Journal of Business and Management (IOSR-JBM), pp. 12-14.

4. Mazeikiene, $\mathrm{N}$ and Gerulaitiene, E. (2018) «Educational aspects of nuclear tourism: sites, objects and museums».Vytautas Magnus University (LITHUANIA), pp. 12-14.

5. McCurry, J. (2018) «There is hope here: Fukushima turns to tourism after nuclear meltdown» The Guardian. Allrights reserved. Retrieved from https://www. theguardian.com/world/2018/oct/17/there-is-hope-here-fukushima-turns-to-tourismafter-nuclear-meltdown

6. National Ecological Centre of Ukraine (2015) «Attitudes of Ukrainians toward nuclear energy national ecological centre of Ukraine» All rights reserved. Retrieved from http://necu.org.ua/stavlennya-naselennya-ukrayiny-do-atomnoyienerhetyky/

7. «NNEG Company «Energoatom». Retrieved from http://www.atom.gov.ua/ en/about-6/mission-7

8. Otgaar, A. (2010)»Industrial tourism: Where public meets the private». Erasmus Research Institute of management, pp. 42-68.

9. Otgaar, A. (2012) «Towards a common agenda for the development of industrial tourism», Tourism Management Perspectives, 4, pp. 86-91.

10. SS «Khmelnytskyi NPP». «KhNPP visitors» Retrieved from http://www.xaec.org.ua/store/pages/ukr/workassign/latest/page.html

11. Stone, P., Hartmann, T., Seaton, R., Sharpley, L., and White, L (2017) «The Palgrave Handbook of Dark Tourism Studies», Palgrave Macmillan, pp. 98-109.

12. State Agency of Ukraine on exclusion zone management (2019), «Statistic of visiting», All rights reserved. Retrieved from http://dazv.gov.ua/en/

13. The Presidential Office of Ukraine (2019) «Head of State signed a decree on the development of the Chernobyl Exclusion Zone» Allrightsreserved. Retrieved fromhttps://www.president.gov.ua/en/news/glava-derzhavi-pidpisav-ukaz-shodorozvitku-chornobilskoyi-z-56321

14. Kalenyuk I., Grishnova O., Tsymbal L., Djakona A., Panchenko E.Formation of intellectual corporate capital: methods and modern trends// Bulletin of National Academy of Sciences of the Republic of Kazakhstan, Volume 6, Number 383 (2020), pp. 182-191. 